\title{
CURRENT STEM CELLS TECHNOLOGIES USED IN MEDICINE
}

\author{
MariaMüller ${ }^{1}$,JuliaCzarnecka ${ }^{1}$,MichałBrzeziński ${ }^{1}$, JakubPrus $^{1}$, Bartosz Kulak ${ }^{1}$,AndrzejHołubowski ${ }^{1}$, \\ Mateusz Stasiak ${ }^{1}$, Blanka Borowiec ${ }^{1}$, Rut Bryl ${ }^{1}$, Lisa Moncrieff ${ }^{1,2}$, Marta Dyszkiewicz-Konwińska ${ }^{3,4}$
}

\begin{abstract}
Stem cells and their usage for a long time are thought to be the future and hope in modern medicine. In this review we summarize development in science and bioengineering in this field. Opening with a description of newly discovered and studied sources of stem cells acquisition we present scientific methods progress and their application like 3D printing or transdifferentiation mode of action and results of these techniques. Technologies of genome editing like transcription activator-like effector nuclease, zinc-finger nucleases, or CRISPR Cas 9 are also presented. In disease treatment and tissue reconstruction stem cells have proved to be effective most times due to great proliferation and differentiation potentials in presented in this summary pre-clinical and clinical studies for diseases like peripheral nerve palsy, myocardial infarction and heart ischemic disease and corneal wound healing.
\end{abstract}

Running title: Current stem cells technologies used in medicine

Keywords: stem cells, stem cells therapy, stem cells use 


\section{Introduction}

Current medical knowledge compared to the past years is on a very high level of development. It lets to diagnose patients in a brief time and to cure most disorders from all body systems. But there is a growing enthusiasm in using stem cells potential in therapy. That's why scientists are looking for newer and newer sources of these cells and trying to develop methods of their studying and modifying to know their physiology and ways of application the best. They try to study their characteristics, features, and potential best, because there is hope for the common use of stem cells in medicine. It would be a groundbreaking discovery. At the same time the technological site of studies is developing there are some pre-clinical and clinical trials done. Although medicine is so strongly developed, surgical and pharmacological methods are on a high level and allow doctors to cure most of the diseases, use of stem cells in therapy as in case of cartilage or optic nerve reconstruction could let to significant improvement of results, treatment methods and their standards. It would also be possible to treat diseases that we can't cure today. However, to succeed in the clinical level of studies there is a need not only for advanced technological facilities, high-level methods of stem cells isolation and study, but also for study and modifying their genome or ways to pass cells into living organisms. Our ability to reprogramming and redirecting cells to gain new properties or to start a new cell lineage other than their natural emphasize the high plastic and malleable nature of the genome. Thanks to that stem cells modification are more and more reliable and faithful to biology, which can be used to repair pathological tissue changes. Because of the presented information, our review contains not only data about the clinical use of stem cells but also scientific achievements in engineering and methods of stem cell research.

\section{The sources and origin of stem cells in the human body and types used in technology}

Stem cells are cells that are undifferentiated or partially differentiated and have an ability to divide into specialized type or types of cells. Stem cells that can differentiate into three germ layers that are: endoderm, mesoderm, and ectoderm are called pluripotent. That means it can differentiate into all the body's cell types. Embryonic stem cells (ESCs), or induced pluripotent stem cells (iPSCs) are examples of them. Multipotent stem cells can also develop into some kinds of cells but only within a specific tissue like haematopoietic stem cells (HSCs). Otherwise, unipotent stem cells have the capability to differentiate into only one cell type for example hepatoblasts.

There are multiple sources of stem cells known for a long time, however, with science development and scientific methods progress new ones are being discovered. There are some sources of stem cells used in medical engineering known for years now like embryonic tissue, fetal tissue such as umbilical cord (Wharton jelly or blood). Moreover, new differentiation features were discovered in somatic cells like bone marrow, skin, peripheral blood or adipose tissue. Now we know that stem cells are present in almost every human tissue. Except mentioned there are niches like epidermis and hair follicles, retina and cornea, pancreas, intestines, liver and dental pulp. Niche is a microenvironment occupied by stem cells where they can be maintained.

Some adult stem cells have an ability to differentiate into various types of tissue. Colin A. B. Jahoda et al. in an experiment run on rats proved that hair follicles stem cells are able to change into adipose and bone tissue [1]. All dermal papilla cells showed evidence of adipogenesis with large lipid globules inside, similarly dermal sheath cell cultures, but two of tested lines showed extensive adipogenesis and the other two only increased lipid production. The study revealed also that three of eight tested clonal lines could produce calcified deposits. This means that finding stem cells in hair follicles can have a clinical perspective and may be used in treatment. Peripheral blood stem cells are also observed to have adipogenic and osteogenic potential. F. Xing from Sichuan University proved that PBSCs have good abilities of osteogenic and adipogenic differentiation and they can be used in making composite cell sheets to repair tissue defects [2].

Already 10 years ago Hugo J. Snippert confirmed that the Lgr6 gene is a marker in hair follicle stem cells which can begin all cell lineages of the skin [3]. And recently it has been proven that also R-spondin protein is responsible for regulating dermal progenitor function. R-spondins may initiate synchronous activation of epithelial and mesenchymal hair follicle regeneration. So secreting R-spondin activates the proliferation of hair follicle dermal stem cells and is an important modulator of stem cell function and tissue regeneration in a variety of organs [4].

Since years we know that mesenchymal stem cells (MSC) can be isolated from bone marrow, adipose tissue and cord blood, but their presence in peripheral blood (PB) was not sure and their amount was supposed to be dependent from inflammation or age (more MSC circulating in elder people) $[5,6]$ A. Jain in a recent study was verifying which factors affect the presence of MSCs in peripheral blood and their relationship with apheresis products [7]. Jain et al. studied the presence of MSCs in PB before and after mobilization with growth factor in patients undergoing autologous stem cell transplantation and healthy donors using flow cytometry. Contrary to predecessors, they didn't find any impact of age on the amount of MSC in blood. Earlier it was thought that MSCs are found in very low numbers in the PB and also this was thesis was denied. In the study 
$42 \%$ of subjects, including both healthy donors and the autologous group, had circulating MSCs. It was higher in healthy donors. It can be a result of prior chemotherapy which possibly decreases the numbers of circulating MSCs. However, it means that healthy people can represent an alternative non-invasive source for MSC for clinical use. Moreover, they noticed no effect of growth factor to the mobilization of MSCs which allow furthering studies.

Some studies have examined the brown adipocytes derived from human fetal interscapular and perirenal depots showed the brown adipogenic potential of brown fat precursor cells isolated during different stages of fetal development is significantly higher than in adults [8,9]. But in $2018 \mathrm{C}$. Zhang et al. for the first time carried out a study about characterization and beige adipogenic potential of human embryo white adipose tissue stem cells (aWAsc) derived from human fetal subcutaneous white fat depots [10]. They compared it with adult white adipose tissue stem cells (eWAsc). By using methods like flow cytometry, real-time PCR and immunoblot they managed to prove that eWAscs have better advantages in adipogenesis capacity and browning/ beiging ability compared to aWAsc. But they differ not only in physiology but also in structure, genetics and kinds of secreting proteins. For example, adipogenic precursor cell markers - defined as CD29+/ CD31-/CD11b-/CD34+ expressing cells in embryo delivered adipose cells are found at lower levels than in adult one. This may say that maybe there are more stem cells and earlier progenitor than preadipocytes with a higher level of pluripotency, proliferation, and differentiation activity in embryo adipose tissue. In summary embryo adipose tissue was found to better undergo cell differentiation and adipogenesis. It perhaps gives us a good source of brown and beige adipocytes which are recognized to be potential therapeutic targets to treat obesity and related metabolic diseases.

Besides the MSCs themselves, there are also more and more knowledge about MSClike cells and their sources. Villard et al. characterized human islet stromal cells (hISCs) and they proved that the cells meet the minimum criteria defining MSCs with adhesion to plastic and expression of a characteristic surface antigen markers including CD73, CD90, and CD105 but also, they maintain pancreatic features. It means they can participate in the reconstitution of a microenvironment very close to the one observed within the pancreas what gives a potential interest in islet transplantation or diabetes cell therapy [11].

Except for stem cells with natural differentiation ability, there are induced pluripotent stem cells (iPSCs). iPSCs are adult cells reprogrammed to begin an embryonic stem cell-like state by being forced to secrete factors relevant important for maintaining the essential features of ESCs. Human iPSCs were first reported in 2007 [12].
To make acquiring iPSCs effective and minimally invasive Ye Huahu run tests to improve earlier methods using Sendai Virus [13]. He proved that peripheral blood is an efficient source of cells to differentiate them into iPSCs. According to the study, as little as $500 \mu \mathrm{l}$ of peripheral blood was enough for the successful derivation of iPSCs without the addition of any reagent for enhancing reprogramming. The data also show that freshly purified PBMCs cultured for 4-6 days enhanced the cell reprogramming efficiency. Thanks to this study the probability of the derivation of clinical-grade human iPSCs for future clinical applications increases. It also confirms peripheral blood to be a safe and easily accessible source of iPSCs [14].

To this day we know that iPSCs can differentiate into many cells like corneal epitheliallike cells [15], mesenchymal stem cells [16], platelets [17], cardiomyocytes [18], neurons [19] to analyse the pathogenesis of diseases, or to check drugs impact on tissues.

\section{Advanced technologies for researching stem cells properties 3D bioprinting}

3D printing is also known as three-dimensional printing. It was first described by Charles W. Hull in 1986. The method is based on additive manufacturing. Thin stratums of material are consecutively printed in layers to form a structure. Materials used for bioprinting are viable cells and biomaterials. They are used to make organs and tissues $[20,21]$.

A particular example of 3D bioprinting is the one that uses stem cells (SCs). These cells have certain functions that make them particularly useful in this process: the ability to form different cell types, self-renewal, viability following encapsulation and printing, pluripotency, resistance to biochemical and biophysical factors for example high temperature, UV light or pressure during encapsulation. Furthermore, mesenchymal stem cells (MSCs) are easily accessible from bone marrow, periosteum and adipose tissue $[20,22]$.

There are three methods of bioprinting: inkjet, microextrusion and laser techniques.

In inkjet technique cells are placed in liquid biomaterials, which is called bioink. By thermal or piezoelectric process they are patterned into drops and thrown out through the micro-nozzles creating the desired shape [21].

Microextrusion is a very popular and cheap method. Biomaterials are extruded mechanically or pneumatically. Bioink is pushed through the microextrusion head making 3D object. This technique allows using higher density material than in inkjet process. Therefore printed structures consist of more cells [22]

Laser techniques are divided into laser-based and laser-assisted bioprinting. The laserbased method is called stereolithography (SLA). It uses UV light to 
cure light-sensitive bioink layer-by-layer [23]. Laser-assisted bioprinting is based on laser-induced forward transfer (LIFT). It uses laser source, donor (upper) slide and lower glassslide. The laser is placed above the donor slide. Laser pulses propel bioink into motion from the upper slide to lower slide, where bioink drops create a structure [24].

An important element in the bioprinting process is the right choice of bioink. Bioinks can be composed of a single biomaterial or they can be multicomponent. Multicomponent bioinks have a significant advantage over a single biomaterial bioinks since they have improved properties [23].

Most often used biomaterials are hydrogels. They have features of the extracellular matrix (ECM) and they are highly hydrated. Hydrogels are produced from i.a. alginate, collagen, fibrinogen, poly(ethylene glycol) dimethacrylate, fibrin, gelatin and other. The right combination of these substances allows to improve the properties of the hydrogel and reproduce the suitable 3D structure [25].

In this review, the results of research on different hydrogel compositions for SCs bioprinting are presented.

Sakai et al. studied behaviours of human adipose stem cells (HASCc) laden in hyaluronic acid/gelatin composite hydrogels obtained through a blue light-induced gelation [26]. Cell behaviours, including the differentiation of SCs, can be changed by the properties of the 3D microenvironment surrounding the cells. By modifying polymer proportion without changing the intensity of blue light the mechanical features of 3D structure can change. HASCs were more elongated in hydrogels with a higher rather than lower concentration of hyaluronic acid (HA) and in hydrogels obtained from gelatin alone. As the HA content increases, stem cell marker genes (Nanog, Oct4, Sox2) become more expressed than in hydrogels with gelatin alone. It has been also proved that hyaluronic acid and gelatin support the maintenance of ASCs differentiation and proliferation potentials.

Kirsch et al. studied how gelatin-methacryloyl (GelMA) formulated with human platelet lysate (hPL) affects mesenchymal stem cell proliferation and differentiation [27]. This groundbreaking study has shown that the addition of hPL directly to the hydrogels had a positive effect on adipose mesenchymal stem cells (AD-MSCs). With higher hPL concentration in hydrogel viability, spreading of AD-MSCs, their proliferation and osteogenic differentiation improved. It shows that hPL provides cells growth factors and adhesion in hydrogels. Also hydrogel's viscosity, stiffness and mechanical strength was batter due to supplementation of hPL.

Benning et al. studied cytocompatibility of hydrogels with MSC to find the most appropriate hydrogel for bioprinting [28]. In this study hydrogels with various concentrations were tested: matrigel, fibrin, collagen, gelatin and gelatin/alginate. This research proved that gelatin/alginate does not support MSC prolifera- tion. Other hydrogels promote high cell viability and proliferation apart from substances concentration. Fibrin with HA addition improved the osteogenic differentiation of MSCs in opposite to collagen gels. Due to this study, the best hydrogels for bioprinting of bone tissue equivalents are fibrin and collagen with HA.

\section{Microfluidic cell sorting}

Flow cytometry is widely used in cell analysis. This technique takes advantage of circumstance that on the cell surface-specific antigenes occur and there are antibodies unique to this antigenes types. Most of SCs do not contain particular markers. This makes accurate identification and separation SCs from other cells problematic [29].

Microfluidics provides cell partition based on their biophysical features, apart from cell-surface markers. Microfluidic techniques for cell sorting are: affinity-based, deterministic lateral displacement, magnetophoresis, inertial microfluidics, acoustophoresis and dielectrophoresis (DEP) [30]. In this review DEP method for SCs is presented.

DEP detects cell features such as surface charge, membrane conductivity and structure, size [29]. DEP is a technique based on cell movement phenomenon due to the polarization effect. This effect is induced by exposing the particle to an electric field. Electric field gradient of alternating or direct current is generated in a microchannel using electrodes. The electric charge gathers on the cell membrane. This leads to an electrical dipole. DEP force depends on the cell's volume and polarizability, the applied voltage and electrode geometry [30-32].

Flanagan et al. verified if the microfluidic system using DEP is useful for characterizing SCs and their progeny [29]. This study was conducted on mouse neural stem/precursor cells (NSPCs) and their derivatives. They proved that NSPCs, neurons and astrocytes have variant dielectric features, which enabled cell differentiation with DEP technique. Due to dielectric features, it is possible to separate and identify progenitor populations and to predict their development lines before cell-surface markers appear and can be detected.

Yoshioka et al. separated bone marrow-derived mesenchymal stem cells (BMSCs) from heterogenic cell compound with bone marrow-derived promyelocytes by the DEP method [33]. As the models of BMSCs the human mesenchymal stem cell line (UET13) were used and human promyelocytic leukaemia cell line (HL-60) as promyelocytes. DEP device separated this cell types without labelling and with preservation of high purity and viability up to $93,6 \%$.

\section{Advanced technologies for in vitro stem cells modification}

One of the most dynamically developing fields of regenerative medicine is transdifferentiation. It is a process that involves the conversion of one cell type into another. 
The advantage of using SCs applied in an autogenic system is no immunological response [34].

Lis et al. converted adult mouse endothelial cells to hematopoietic stem cells (rECHSC) [35]. Expression of genes coding the transcription factors and vascular-niche-derived angiocrine factors was used. Received cells were stable, self-renewing had all bona fide HSC's features and were able to differentiate into all hematopoietic lineages. Even after 20 months, cells did not undergo malignant transformation. This type of research aims to use easily accessible sources like autologous endothelial cells for transformation into HSCs, which in future can be used in hematological disorders treatment.

Dai et al. in vitro transdifferentiated ASCs into salivary gland acinar-like cells (SGALCs) and examined the influence of platelet-rich fibrin (PRF) on this process [36]. ASCs were isolated from the mouse inguinal fat pads. Expression of $\alpha$-amylase and AQP-5 were used for transdifferentiation evaluation. Co-culture study lasted only for 21 days, the conversion was $50 \%$ successful. The study showed that PRF supports the process. Research like these is being conducted to enter treatment for salivary gland hypofunction, which occurs after radiotherapy used as head and neck cancer cure.

Shivakumar et al. isolated MSCs from one donor's three dental tissues: pulp, papilla and follicle and compared in vitro differentiation potential towards pancreatic $\beta$ cell-like cells [37]. All three types of MSCs converted into pancreatic-like insulin-producing cells, which was tested with dithizone staining and glucose challenge test. It was proved that follicle MSCs have the best differentiation potential. Results suggest that one donor's MSCs isolated from different dental tissues have various converting potential toward different lineages. It was suggested that in the future MSCs may be used as an autologous source of SCs for allogeneic transplantation and follicle MSCs have the potential to be used in diabetes treatment.

\section{Cellular and tissue bioengineering based on stem cells \\ Bioengineering based on stem cells}

Nowadays, after years of endeavouring to find a method of formation of human organs and tissues using stem cells, we are in a promising position. Modern science allows for spheroids and organoids production, and usage of novel techniques such as bioprinting. Many of the preclinical tests pave the roads for starting treatments of many diseases, especially skin and cartilage defects. That is the chance not only in plastic surgery but also in genetic or degenerative diseases therapy.

\section{Spheroids}

Aggregates of cells produced on the base of stem cells called spheroids are most common plane of bioengineering. The fact, that spheroids are 3D makes them more similar to alive cells clusters than their 2D models. Their possibility of dissociation into single cells provides an option of so important flow cytometric analysis. The 2017 research pointed predominance of co-cultivation of normal human dermal fibroblasts with human dermal microvascular endothelial cells (HDMEC) than HDMEC monoculture spheroids [38].

Their resemblance to entourage prevailing in human tissues ensures a more effective evaluation of medication's properties than testing on animals.

Spheroids pave the road to a better understanding blood-brain barrier (BBB) due to the possibility of getting its similar conditions in vitro. This model, described in 2017 article, easy to culture and presenting high reproductivity, helps to get to know BBB drug transport. That could develop brain-penetrant drug usage in central nervous system diseases [39].

Tests on spheroids also bring more reliable results in toxicity tests. Toxicity is often other in animal models than for the human. In the research, the CD-spheroid system was used and presented well sensitivity, and specificity in drug assays. That fact will permit to lower complications in clinical phases in drug testing [40].

Spheroids are also important objects in researches focused on tumor therapy. Possibility of getting 3D scaffold-free models of the tumor components almost perfect imitating real cancer constituents gives a chance of progress in treatment testing without the patient's exposure. That hopes patients with pancreatic ductal adenocarcinoma (PDAC), whose prognosis is often weak. Spheroid constructed in 2018 co-culture of pancreatic cancer cells, fibroblasts and endothelial cells - created microenvironment allowing for studying drug sensitivity of PDAC cells, which could predict their behavior in vivo [41].

Spheroids are safer and more accurate alternatives for testing on animals, what makes more proper selection of drugs and their doses in following clinical usage. They also allow for getting knowledge about mechanisms specific to the human tissues.

\section{Organoids}

Organoids are 3D multicellular structures based on pluripotent stem cells or cells derived from adult organs, especially tumour cells. Progress in control of their high variability and diversity during development thrives on their common usage in the near future.

One of the most frequent organs which is the target of forming organoids is a brain. 3D brain organoids allow for studying human brain development and diseases (often congenital). Also, higher-level brain functions and neuropsychiatric pathologies might be demonstrated in brain organoids. That was pointed out in 2017 research describing the usage of light stimulation to control neuronal activity, which showed the possibility of sensory stimulation 
in vitro [42]. Another manuscript from 2018 focused on brain vascularization. It was firstly proved, that organoids built up of one's patient induced pluripotent stem cells and endothelial cells let generate human vascularized brain organoid [43].

Organoids are also a chance for finding precision cancer therapy. Patient-derived bladder organoids show tumor development in vitro what can be easily referred to in vivo tumor features such as drug response or resistance. In 2018 research scientists pointed significant tumor organoids heterogeneity in culture what forces the next step, that is to say, co-clinical studies on evaluation of organoids response to treatment in correlation with in vivo therapy [44]. Other 2018 research focused on breast cancer (BC). They made an effort to construct a living biobank of $\mathrm{BC}$ organoids. It could be a huge step to select a base of models to carry out preclinical, clinical, and pharmaceutical tests with a proper subtype of BC [45].

In 2018 scientists worked on hepatocyte organoids. They received a long-term 3D organoids for mouse and human based on single hepatocyte, reaching adequate functional, morphological, and genetic conditions. The possibility of observing hepatocytes proliferation and regeneration in vitro allows for a better understanding of hepatic diseases and liver participation in detoxification [46].

\section{Skin reconstruction}

Skin is especially exposed to injuries and permanent defects, like wounds or burns. Treatment in that case, is difficult, due to the necessity of founding repeatedly huge quantity of skin analog which should be physiologically and histologically almost identical. The chance for that is still progressing researches focusing on stem cells usage.

One of the newest articles from 2019, describes the usefulness of 4 types of mesenchymal stem cells (MSCs): adipose-tissue-derived stem cells (ADSCs), dental pulp stem cells (DPSCs), Wharton's jelly stem cells (WJSCs) and bone marrow stem cells (BMSCs) as the base to yield heterotypical human bioengineered skin. Scientists evaluate each of the MSCs type paying attention to their ability to cytokeratin 10 and filaggrin expression and absence of human leukocyte antigen (HLA). Considering the first condition, WJSCs and BMSCs found the best and referring to lack of HLA, ADSCs, DPSCs and WJSCs bode well. Concluding, they recommend WJSCs as the best type of MSCs to use in the clinics [47].

Other research from 2018 shows how important is to find a property bioink to get an effect of fast neovascularization in 3D-bioprinted patches in vivo. It was used skin-derived extracellular matrix (S-dECM) laden endothelial progenitor cells (EPCs) as bioink together with ADSCs to create a skin patch. That allows for getting easy and fast re-epithelization, neovascularization, and wound closure during an experiment on the nude mice. If tests on the bigger animals, which skin structure is more similar to humans are positive, it will be a huge step to start pre-clinical and clinical applications [48].

These and other researches in the field of bioengineering ensure common use of stem cells in skin diseases and injuries treatment. Scientists from Bochum (Germany) and Modena

(Italy) pointed usefulness of transgenic stem cells in the Junctional Epidermolysis Bullosa cure [49]. Probably more dermal problems could be solved by MSCs.

\section{Cartilage reconstruction}

Cartilage defects are common reasons for disabilities. The specifics of this group are difficulty in pharmacological treatment. The new way to solve this problem is through the exploration of bioengineering techniques. Cartilage turns out to be one of the most explored topics in the field of bioengineering. Many of the newest researches allow us to think that in the coming time we will hear about human cartilage reconstruction using stem cells.

Research published in 2017 evaluates the usefulness of multipotent articular cartilage resident chondroprogenitor cells (ACPCs) opposite to bone marrow mesenchymal stromal cells (MSCs) in cartilage bioengineering and usage of gelatin methacryloyl (gelMA)-based hydrogels used to culture ACPCs, MSCs and chondrocytes, as bioink. The first cue hidden in this research is that MSCs may show higher ability in producing ECM substitutes, but ACPCs may cut down on collagen type-X production and increase PRG4 expression, what could allow to yield more similar to superficial zone chondrocytes matrix. In the result, co-cultures of ACPCs and MSCs will expand the capabilities of cartilage bioprinting [50]. Next researches focusing on ACPCs will probably find new ways to get substance more proper to use in therapy.

The other research from 2018 performed on rabbits' cartilages showed that it is probably possible to treat cartilage injuries using mesenchymal stem cells (MSCs) prepared on the hydrogel scaffold in vitro and then implanted to a real joint in vivo. Scientists proved the utility of hydrogel scaffold $\mathrm{ACM}+\mathrm{RAD} / \mathrm{PFS}$ as the matrix goodly homing stem cells and accelerating the chondrogenesis process [51]. Success in cartilage tissue repairing in vivo let us recognize this method as potentially useful in clinics.

In proper production, level of synovial fluid (SF) is low, but in osteoarthritic (OA) it increases, what prompted scientists to focused on SF-MSCs in 2018 research. Easy way to download it during arthrocentesis or arthroscopy allows to yield easily SF-MSCs, which could be used to perform stem-cells-based reconstruction of cartilage defects. The experiment on the nude rats' knees showed, that the similarity 
of OA SF-MSCs will help chondrogenesis due to its possible chondroprotective properties [52].

Still, ongoing researches on cartilage reconstruction using stem cells discover many new ways to acquisition stem cells, which can be useful in chondrogenesis, as well as new scaffolds property conducting reconstruction of cartilage. These discoveries could allow treating diseases like osteoarthritis, osteonecrosis, or rheumatoid arthritis using bioengineering techniques.

\section{Technologies of genome editing used in modifying stem cells}

This section will discuss and briefly compare mechanisms of chosen technologies that are being used in the genome editing of stem cells.

\section{TALEN (Transcription activator-like effector nuclease) \\ Mechanism \\ Transcription activator-like effector nucleases} (TALEN) are restriction enzymes able to cut certain sequences of DNA. They are made of fused TAL effector DNA-binding domain and a DNA cleavage domain. Transcription activator-like effectors (TALEs) can be designed to bind to any chosen DNA sequence, so when combined with a nuclease, DNA may be cut at specific locations.

TALEs are proteins occurring in the plant pathogenic bacteria genus Xanthomonas, containing DNA-binding domains composed of a series of 3335 amino acid repeat domains each identifying a unique base pair.

Two hypervariable amino acids, known as the repeat-variable diresidues (RVDs) define TALE specificity. Modular TALE repeats are bound together to identify contiguous DNA sequences.

In order to build hybrid nucleases, the non-specific DNA cleavage domain from the end of the FokI endonuclease can be used. The FokI domain operates as a dimer, demanding two constructs with particular DNA binding domains for sites in the target genome with appropriate location. The number of amino acid residues between the TALE DNA binding domain and the FokI cleavage domain as well as the number of base pairs between the two individual TALEN binding sites are crucial for achieving high levels of activity [53-56].

Because of the identical repeat sequences, cloning of repeat TALE arrays is highly challenging. In order to manage with this problem, various methods have been designed to allow putting together custom TALE arrays, such as "Golden Gate" molecular cloning, high throughput solid-phase assembly and ligation-independent cloning techniques. Various studies exploiting diverse assembly methods have shown that TALE repeats can be put together to recognize any user-defined sequence [55].

\section{ZFNs (Zinc-finger nucleases)}

Mechanism

Zinc-finger nucleases (ZFNs) are artificial restriction enzymes built by fusion of DNA cleavage domain and zinc finger DNA-binding domain. Zinc finger domains can be designed to target certain DNA sequences and this allows zinc-finger nucleases to target desired sequences within complex genomes.

Generally between three and six individual zinc finger repeats are included in particular ZFNs of The DNA-binding domains and each can recognize between 9 and 18 base pairs. If the zinc finger domains identify a 3 base pair DNA sequence, they can form a 3 -finger array that can distinguish a 9 base pair target site. In order to create zinc-finger arrays with six or more specific zinc fingers, 1-finger or 2-finger modules can be utilized by different mechanisms.

Type IIs restriction endonuclease FokI is most commonly used as the non-specific cleavage domain in ZFNs.

In order to cleave DNA the cleavage domain has to dimerize, therefore a pair of ZFNs are necessary to target non-palindromic DNA sites. The C-terminus of each zinc finger domain is fused to the cleavage domain in standard ZFNs. The two individual ZFNs have to bind opposite strands of DNA with their C-termini a specific gap apart to let the two cleavage domains dimerize and cleave DNA. The most generally used linker sequences between the cleavage domain and the zinc finger domain requires the 5 ' edge of each binding site to be divided by 5 to 7 base pairs.

Dimerization of the cleavage domain is a great advantage, thanks to a monomer not being active, cleavage does not appear at single binding sites.

The cleavage reagent is built at the target only if the fingers have sufficient specificity, therefore the requirement for binding two proteins brings the total specificity into a very useful range [57-59].

\section{CRISPR Cas9 (Clustered Regularly Interspaced Short Palindromic Repeats)}

Mechanism

Clustered regularly interspaced short palindromic repeats (CRISPRs) are adapted from RNA-based adaptive immune systems that act by eliminating bacteriophages of Streptococcaceae [60]. CRISPRs consist of short RNA sequences and Cas 9 protein. Cas 9 is an endonuclease which is able to make a cut in DNA molecules targeted by short RNAs. The short RNAs contain two noncoding RNAs, a CRISPR RNA (crRNA), and a transactivating crRNA (tracrRNA). When bacteriophages invade the bacteria, the CRISPR nuclease identifies and cleaves protospacer adjacent motifs (PAMs) in target viral DNA, during another infection by the same virus, this integrated sequence is transcribed and acts to lead the CRISPR to cleave the viral genome. The Cas 9 of the CRISPR 
system needs complementary base pairing between crRNA, tracrRNA, and target DNA to work efficiently in vitro [8-10]. A conserved PAM sequence, $\mathrm{NGG}$, on the target DNA strand acts to recruit the Cas9-crRNA-tracrRNA complex to the targets seed region [61]. The seed region is composed of about seven bases near the PAM sequence, and is the place of pairing of the crRNA and target DNA. The seed region enables the establishment of DNA binding specificity, and mutations in this region prevent Cas9-mediated cleavage of the target DNA [60].

The cleavage sites on individual target DNA strand are specified by the PAMs, the sites are cleaved by particular domains of Cas9 - the RuvC-like domain cleaves the non complementary strand, and the $\mathrm{HNH}$ domain which cleaves the strand complementary to the crRNA, the correlation of both domains causes double stranded breaks in the target DNA $[60,61]$.

To increase the specificity and viability, the CRISPR system has been reengineered. A single chimeric guide RNA (gRNA) has been created by fusing the crRNA and tracrRNA. The gRNA imitates natural base pairing correlation between tracrRNA and crRNA. The efficiency of the tracrRNA-crRNA duplex and the chimeric gRNA is comparable $[62,63]$.

\section{Biotechnology of stem cells}

Wnt signalling pathway is significant in stem cells differentiation and proliferation. This pathway functions through a beta-catenin increasing activity of transcription factors concerned with differentiation, embryogenesis or carcinogenesis [64]. Usage Wnt ligands is possible with initiated trans-differentiation type 2 alveolar epithelial cells (AT2) to type 1 alveolar epithelial cells (AT1). AT2s behave as stem cells and are responsible for regeneration after alveolar epithelium injury. In vitro treatment with several Wnt ligands on AT2-like cells downregulates specific AT2 markers and upregulates AT1 markers, however there are significant differences with influence of particular Wnt ligands in the process [65]. It has been confirmed that also the environment has an influence on the activity of Wnt pathway and then through transcriptional mechanism initiates trans-differentiation [66].

Wharton Jelly-derived mesenchymal stem cells are a valuable kind of stem cells, they have higher differentiation potential than bone marrow stem cells, hence recently WJMCSs has become an interesting subject of investigation. It has been confirmed that WJMSCs show an expression of factors like Oct4, Sox2 and Nanog which are responsible for maintaining pluripotency of stem cells [67]. Satheesan and partners have obtained transdifferentiation of WJMSCs to neuronal stem cells, by treatment of neuronal conditioned medium sourced from cultured brain cells, without any exogenous growth factors. In this method neuronal-like cells obtained contain of expression of specific neuronal-markers and even interconnections between cells characteristic for neural tissue, which can indicate that obtained cells are valuable [68]. However, the investigation was performed on an animal model, this kind of trans-differentiation of human WJMSCs should be examined in the future.

MCSs isolated from Whorton Jelly can be reprogrammed to the functional cells using epigenetic methods. Bhuvanalakshmi and partners obtained cardiomyocytes from MCSs using DNA methyltransferase 1 specific inhibitor (DC301) and specific histone deacetylase 1 inhibitors (DC302). The inhibitors initiate changes in the chromatin structure, which probably allows expression of genes responsible for myocardial differentiation and development as Nkx2.5 and GATA4. MSC-derived cardiomyocytes contained specific cardiac proteins and did not show expression of specific markers present in noncardiac cells [69]. However, transdifferentiation would not be useful in therapy, if proliferation properties of stem cells are not maintained.

Stem cells proliferation is a significant property which should be considered as prospecting possible therapy methods. In spite of MSCs are relatively easy to isolate, capable of multilineal differentiation and safety in therapy, MSCs have restricted ability to proliferate in culture [70]. There are investigations indicating that non-thermic atmospheric pressure plasma (NTAPP) has a positive influence on proliferation of MSCs. NTAPP is a partially ionized gas composed active species [71] and is capable of producing reactive oxygen and nitrogen species, which are responsible for various biological effects [72]. It has been showed that NTAPP activates proliferation of hematopoietic (HSC), adipose tissue-derived (ASC) and bone marrow-derived stem cells (BMSC). Furthermore, the treatment of NTAPP significantly increases expression of stemness markers like CD44 and CD105 and also activates and maintains expression of pluripotent markers (Oct4, Sox2, Nanog). The influence of NTAPP on the processes in comparison to high concentrations of glucose and b-FGF is bigger [73]. NTAPP activates an expression of cytokine and growth factors (primarily they are required for a proliferation in vitro) and decreases expression of genes apoptotic pathway. Epigenetic modifications are responsible for the changes in expression [74].

Immortalization and increase of proliferation rate of BMSC can be obtained with CRISPR/Cas9 method. This is an interesting genome-editing technology which has advantages over commonly using methods as TALEN or use of viral vector [75]. Insertion of SV40T gene to safe-locus in genome is an efficient way to reversibly immortalize cell through expression of SV40T protein which inactivates genes ( $\mathrm{p} 53, \mathrm{Rb})$ responsible for preventing proliferation of cell in an uncontrolled way. The immortalized BMSCs with CRISPR/Cas9 in comparison 
to immortalized with the same gene but with viral vector exhibit decreased proliferation rate. However, the immortalization can be reversed easier in the first cells. What is more important, both kinds of methods have a long-term proliferation capability. The results indicate that this technology can be a valuable source of MSCs [76].

CRISPR/Cas9 system can be used also for regulating DNA methylation selectively and through this activated expression of a particular gene. This technology was used to induce expression of Oct4 gene [77]. Overexpression of Oct4 improves proliferation capacity of cells and can upregulate expression of Nanog and Sox2 and primarily maintain the morphology of MSCs. Thus, possible, that similar methods can be used to obtain valuable MSCs for stem cells therapy [78].

\section{Preclinical studies}

A brief review of some preclinical studies on the application of stem cells in the treatment of several diseases using animal models is contained in this section.

\section{Peripheral nerve palsy}

Usage of human muscle-derived stem/progenitor cells (hMDSPC) in sciatic nerve injury in the murine model showed nerve regeneration. The reversal of muscle atrophy and recovery of functional movement were observed. In 72 weeks after transplantation of hMDSPC into mice with sciatic nerve injury, no significant differences in the weight of gastrocnemius muscle between research and control group (mice with working properly sciatic nerve) were noticed. Moreover, no adverse effects were observed in animals up to 18 months after transplantation [79].

\section{Myocardial infarction and heart ischemic disease}

Due to the fact that pigs are nearly like humans when it comes to physiology and anatomy of heart, they are an excellent models to establish efficacy and safety of stem cell therapy in the treatment of ischemic heart disease and myocardial infarction.

Transplantation of adipose-derived stem cells (ADSCs) sheet on the ischemic area of the swine myocardium with induced chronic failure 8 weeks after intervention showed a significant increase in the left ventricular ejection fraction (LVEF). Furthermore, in cases with right coronary angiography, the development of collateral vessels was detected. However, no statistically significant differences in the Rentrop score were observed between research and control group [80]. In similar research using ADSCs but set through the intramyocardial injection route, improvement in LVEF was noticed. Additionally, infarct size was decreased [81].

Fresh, uncultured, unmodified, autologous adipose-derived regenerative cells (UAADRCs) were used for treating chronic myocardial infarction (MI) in the porcine model. Cells were delivered in $10 \mathrm{~mL}$ saline through the jugular vein into the coronary sinus by an angioplasty balloon. The control group received $10 \mathrm{~mL}$ saline alone. Results in the research group were statistically significant. Delivery of UAADRCs increased LVEF, cardiac output, the mass of the left ventricle and reduced scar volume of the left ventricular wall [82].

\section{Stents in the treatment of coronary artery disease}

Coronary artery disease is treated with the use of coronary stents which keeps the arteries open. The problem of such a method is restenosis and stent thrombosis causing failure of the treatment. A study on the porcine model with coronary stents coated with umbilical cord blood-derived mesenchymal stem cells (UCB-MSCs) gives hope to be a solution to the previously mentioned problems. Those cells produced a hepatocyte growth factor (HGF) and vascular endothelial growth factor (VEGF) in five to one ratio. That resulted in restenosis reduction and promotion of re-endothelialization what provided the best blood flow comparing other ratios of HGF+VEGF and bare-metal stents [83].

\section{Corneal wound healing}

The greatest challenges in corneal wound healing are structural changes of recovering cornea such as scar formation, often leading to blindness or reduction of vision clarity.

Usage of human placenta-derived mesenchymal stem cells (hP-MSCs) extracellular vesicles (EVs) in alkali burn injury of the cornea in the mouse model improved healing. Results of the study indicate that hP-MSC-derived EVs inhibited inflammation and apoptosis, regulated the angiogenesis and increased tissue repair. After seven days of treatment in EVs treated group corneal epithelium recovered 4-5 cell layers of structure with a quite regular matrix arrangement [84].

Umbilical cord mesenchymal stem cells (uMSCs) derived from the Wharton's Jelly, injected subconjunctivally, reduced corneal scar formation in the treatment of fungal keratitis (FK) in a mouse model. Injection of uMSCs was combined with antifungal treatment [85].

\section{Burn derived mesenchymal stem cells (BD-MSCs)}

In patients with third-degree skin burn, damaged tissue that most commonly is excised and then destroyed as medical waste, according to cited research seems to be an excellent source of mesenchymal stem cells (MSCs) that can be used for wound healing and skin regeneration. Research on burned skin wounds in the murine and porcine model showed that usage of BD-MSCs accelerated the healing process and reduced the scar formation. No adverse effect has been observed. Results give hope for an easily accessible scalding therapy [86]. 


\section{Section summary}

Results of the presented researches indicate on beneficial action of used methods of treatment. Although more similar attempts with bigger research and control groups are needed to demonstrate recurrence.

\section{The use of stem cells in advanced human clinical trials}

Numerous studies are carried to show the usefulness of stem cell therapy for various disorders. Many of them are the answer to the most urgent problems of modern medicine like stroke, myocardial infarction, cartilage disorders, neurodegenerative diseases, diabetes.

This chapter presents the most promising and current of them.

\section{Stroke}

There are two major methods reported for clinical cell therapy in stroke: intravenous injection and intracerebral grafts [87]. A new study using the first method was performed. There was a target to examine the safety and preliminary efficacy estimates of intravenous allogeneic mesenchymal stem cells in the population of patients with chronic stroke and substantial functional deficits. The study was designed to consider dose-escalation up to 1.5 million cells $/ \mathrm{kg}$. None of serious adverse events and deaths were related to stem cell treatment. Based on electrocardiograms, laboratory tests, and computed tomography scans of chest/abdomen/pelvis, it was found that the treatment was safe. Furthermore, in all behavioural endpoints, a significant increase was noticed (for example Barthel Index) [88]. However, considering a small research sample - a randomized, placebo-controlled study of this therapy is needed.

Another important study used a single dose of up to 20 million cells by stereotactic ipsilateral putamen injection. There was an improvement in the relevant indicators. There were not noticed any cell-related adverse event, however (asymptomatic) side effects related to neurosurgical procedure occurred in 4 of 11 patients. Although overall safety has been confirmed [89]. Recently this year continuation of that studies has been published, which gave more information about this method. The group of patients who underwent the procedure was larger with a single intracerebral dose of 20 million CTX cells (no dose escalation). The ischaemic stroke had occurred between 2 - 13 months earlier before the procedure which is a shorter time than in the previous stage. The improvement in the Action Research Arm Test (ARAT) was seen in every patient except those with absent upper limb movement at baseline [90].

Differences between results of these studies indicate some unsolved problems [87] however, they show a promising perspective.

\section{Neurodegenerative disorders and spinal cord injury}

An extensive study from a year ago examined the safety and therapeutic potential of stem cells in several disorders (Alzheimer's disease, amyotrophic lateral sclerosis, progressive multiple sclerosis, Parkinson's "Plus", spinal cord injury, traumatic brain injury, stroke). Intracerebroventricular brain injections were safe in this trial although adverse effects occurred similar to other studies using this procedure. Clinical improvement was particularly promising in Alzheimer's disease and progressive multiple sclerosis patients [91]. Studies targeting amyotrophic lateral sclerosis demonstrated the safety of single-dose transplantation of mesenchymal stem cell - neurotrophic factor as well as early signs of efficiency for this therapy. A multidose randomized clinical trial is needed [92]. Other study on amyotrophic lateral sclerosis indicate dose-dependent efficacy but clearly draws attention to painful response at higher doses [93].

Another widely discussed problem is the feasibility of stem cells in treating spinal cord injuries. Clinical trials are ongoing to check which kind of therapy results in the best effects. Studies confirmed the safety of intramedullary central nervous system stem cells transplantation and feasible using a manual injection technique with dose escalation, giving moderately promising clinical results [94]. Similar conclusions are from another study without dose escalation. However, it notes that there is a lack of statistical power to evaluate functional changes resulting from cell grafting [95]. On the other hand, there is the study which suggests using a functional collagen scaffolds transplantation combined with umbilical cord mesenchymal stem cells and gives significant therapeutic progress at a patient with complete spinal cord injury [96].

\section{Myocardial infarction}

Acute myocardial infarction (AMI), as well as other cardiovascular diseases, are the leading death cause worldwide [97]. A lot of research is being done to improve the quality of life of people with this kind of disorders. The studies comparing conventional treatment - coronary artery bypass graft (CABG) with CABG supported by bone marrow mononuclear cells (BMMNC) in terms of a function of the left ventricle, indicate statistically significant improvement in novel therapies. Cardiac function was assessed by an echocardiography and single-photon emission computed tomography (SPECT). Safety of these therapies has also been demonstrated $[98,99]$. There are carrying out clinical trials with other types of stem cells. High level of safety was confirmed in the use of Intracoronary Infusion of Allogeneic Human Cardiac Stem Cells, but the change in infarct size was not satisfying in this trial [100]. However, in another in- 
novative trial, the focus was on Umbilical Cord Mesenchymal Stem Cells (UCMSCs), achieving significant results both in imaging and other indicators (New York Heart Association functional class, Minnesota Living with Heart Failure Questionnaire) improving quality of patients' life. Nonetheless, the group treated with UC-MSCs did not differ in mortality, heart failure admissions, arrhythmias and incident malignancy with placebo group 12 months after the study completion [101]. Combination (bone marrow mesenchymal stem cells with cardiac progenitor cells) studies are also being conducted [102].

\section{Osteoarthritis}

There is a lot of research regarding the usefulness of stem cells in osteoarthritis treatment which give promising results. Randomized, Placebo-Controlled Clinical Trial used an intra-articular injection of autologous AD-MSCs for patients with knee osteoarthritis. Outcome measures included various clinical and radiologic examination and Western Ontario and McMaster Universities Osteoarthritis Index (WOMAC). No serious adverse events occurred at 6 months, at the same time the significant improvement of the WOMAC score was observed as well as pain relief for patients was provided [103]. There are also studies on dose escalation of ADMSCs repeated injection, where an increase in cartilage volume of the knee joint was achieved [104]. A wider study also exists. It compares increasing doses of BMMSC in combination with hyaluronic acid intraarticular administration, with hyaluronic acid alone as a control group. Among other methods, the WOMAC scale was used for the assessment of pain and function. The high-dose group proved to be significantly more effective and resulted in clinical and functional improvement of the knee [105].

The continuation of this study was published after long term follow up (4 years) and confirmed previous findings using VAS and WOMAC scorings [106]. Another clinical trial conducted even more extended follow up lasting 7 years, using many types of research at the time. The product composed of allogeneic human umbilical cord blood-derived mesenchymal stem cells and hyaluronic acid hydrogel was administered by arthroscopy. Therapeutic effect was significant and persistent [107]. Data from studies on a larger control sample also bring positive conclusions and significant improvement in knee pain and quality of life [108].

\section{Diabetes}

Intensive research is being conducted into the use of stem cells to support diabetes management. Promising results were achieved in preserving $\beta$-cell function in new-onset type 1 diabetes which was analysed as C-peptide concentrations in blood in response to a mixedmeal tolerance test at 1 year follow up. MSC-treatment was established as safe
[109]. Significant improvement in insulin sensitivity with MSCs and increase in C-peptide response was also achieved in type 2 diabetes using both autologous bone marrow-derived mesenchymal stem cells and mononuclear cells [110].

\section{Conclusions}

Stem cells and their usage for a long time are considered to be the future of modern medicine. There is a need of study of stem cell characteristics, features, and potential, to allow their common use in medicine. In this broad review we discussed the sources and origin of stem cells in the human body, advanced technologies for researching stem cells properties like 3D bioprinting, microfluidic cell sorting and advanced technologies for in vitro stem cells modification. We reviewed cellular and tissue bioengineering based on stem cells - spheroids, organoids, skin and cartilage reconstruction. We also discussed the case of technologies of genome editing used in modifying stem cells, like TALEN, Zinc-finger nucleases and CRISPR Cas9. Biotechnology of stem cells was described with details as well. Preclinical studies were also significant in this review, as we discussed peripheral nerve palsy, myocardial infraction and heart ischemic disease, stents in the treatment of coronary artery disease, corneal wound healing, burn derived mesenchymal and stem cells. Numerous conditions like stroke, neurodegenerative disorders, myocardial infarction, osteoarthritis and diabetes were debated and described in the context of stem cells. This review contains a great deal of valuable information for researchers wishing to further understand stem cells and their mechanisms. As can be seen, research on them is certainly advanced, but this should not prevent the development of new aspects of stem cell use in medical sciences. On the contrary, it should encourage more and more detailed research and gaining a new perspective on stem cells and their usage.

\section{Ethical approval}

The conducted research is not related to either human or animal use.

\section{Acknowledgements}

Not applicable.

\section{Corresponding author}

Marta Dyszkiewicz-Konwińska, Department of Biomaterials and Experimental Dentistry, 70 Bukowska St., 60-812 Poznań, Poland and Department of Anatomy, Poznan University of Medical Sciences, 6 Święcickiego St., 60-781 Poznań, Poland, Tel./Fax: +48 61 8546565, e-mail: m.dyszkiewicz@ump.edu.pl.

\section{Conflict of interest statement}

The authors declare they have no conflict of interest.

\section{References}

1. Jahoda CAB, Whitehouse CJ, Reynolds AJ, Hole N. Hair follicle dermal cells differentiate into adipogenic and osteogenic lineages. Exp Dermatol. 2003;12:849-59; DOI:10.1111/j.0906-6705.2003.00161.x.

2. Xing F, Duan X, Liu M, Chen J, Long C, Chen R, Sun J, Wu S, Chen L, Xiang Z. Construction and preliminary study on biological characteristics of 
composite cell sheets of mesenchymal stem cells and endothelial progenitor cells derived from peripheral blood. Zhongguo Xiu Fu Chong Jian Wai Ke Za Zhi. 2020;34:109-15; DOI:10.7507/1002-1892.201901087.

3. Snippert HJ, Haegebarth A, Kasper M, Jaks V, Van Es JH, Barker N, Van De Wetering M, Van Den Born M, Begthel H, Vries RG, Stange DE, Toftgård R, Clevers H. Lgr6 marks stem cells in the hair follicle that generate all cell lineages of the skin. Science (80- ). 2010;327:1385-9; DOI:10.1126/science.1184733.

4. Hagner A, Shin W, SinhaS, Alpaugh W, Workentine M, Abbasi S, Rahmani W, Agabalyan N, Sharma N, Sparks H, Yoon J, Labit E, Cobb J, Dobrinski I, Biernaskie J. Transcriptional Profiling of the Adult Hair Follicle Mesenchyme Reveals R-spondin as a Novel Regulator of Dermal Progenitor Function. IScience. 2020;23:101019; DOI:10.1016/j.isci.2020.101019.

5. Beane OS, Fonseca VC, Cooper LL, Koren G, Darling EM. Impact of aging on the regenerative properties of bone marrow-, muscle-, and adipose-derived mesenchymal stem/stromal cells. PLoS One. 2014;9; DOI:10.1371/journal.pone.0115963.

6. Raggi C, Berardi AC. Mesenchymal stem cells, aging and regenerative medicine. Muscles Ligaments Tendons J. 2012;2:239-42.

7. Jain A, Khadwal A, Sachdeva MUS, Bose P, Lad D, Bhattacharya S, Prakash G, Malhotra P, Varma N, Varma S. Variables affecting the presence of mesenchymal stromal cells in peripheral blood and their relationship with apheresis products. Br J Haematol. 2020;189:772-6; DOI:10.1111/bjh.16412.

8. Svensson PA, Lindberg K, Hoffmann JM, Taube M, Pereira MJ, Mohsen-Kanson T, Hafner AL, Rizell M, Palming J, Dani C, Svensson MK. Characterization of brown adipose tissue in the human perirenal depot. Obesity. 2014;22:1830-7; DOI:10.1002/oby.20765.

9. Wu NN, Zhang CH, Lee HJ, Ma Y, Wang X, Ma XJ, Ma W, Zhao D, Feng YM. Brown adipogenic potential of brown adipocytes and peri-renal adipocytes from human embryo. Sci Rep. 2016;6:1-12; DOI:10.1038/ srep39193.

10. Zhang C, Wang JJ, He X, Wang C, Zhang B, Xu J, Xu W, Luo Y, Huang K. Characterization and beige adipogenic potential of human embryo white adipose tissue-derived stem cells. Cell Physiol Biochem. 2018;51:2900-15; DOI:10.1159/000496042.

11. Villard O, Armanet M, Couderc G, Bony C, Moreaux J, Noël D, Devos J, Klein B, Veyrune JL, Wojtusciszyn A. Characterization of immortalized human islet stromal cells reveals a MSC-like profile with pancreatic features. Stem Cell Res Ther. 2020;11:158; DOI:10.1186/ s13287-020-01649-z.

12. Takahashi K, Tanabe K, Ohnuki M, Narita M, Ichisaka T, Tomoda $K$, Yamanaka S. Induction of pluripotent stem cells from adult human fibroblasts by defined factors. Cell. 2007;131:861-72; DOI:10.1016/j. cell.2007.11.019.

13. Soares FAC, Pedersen RA, Vallier L. Generation of human induced pluripotent stem cells from peripheral blood mononuclear cells using sendai virus. Methods Mol. Biol. Humana Press Inc. 2016;1357:23-31; DOI:10.1007/7651_2015_202.

14. Ye H, Wang Q. Efficient Generation of Non-Integration and Feeder-Free Induced Pluripotent Stem Cells from Human Peripheral Blood Cells by Sendai Virus. Cell Physiol Biochem. 2018;50:1318-31; DOI:10.1159/000494589.

15. Kamarudin TA, Bojic S, Collin J, Yu M, Alharthi S, Buck H, Shortt A, Armstrong L, Figueiredo FC, Lako M. Differences in the activity of endogenous bone morphogenetic protein signaling impact on the ability of induced pluripotent stem cells to differentiate to corneal epithelial-like cells. Stem Cells. 2018;36:337-48; DOI:10.1002/stem.2750.

16. Wang LT, Jiang SS, Ting CH, Hsu PJ, Chang CC, Sytwu HK, Liu KJ, Yen BL. Differentiation of mesenchymal stem cells from human induced pluripotent stem cells results in downregulation of c-myc and dna replication pathways with immunomodulation toward cd 4 and cd8 cells. Stem Cells. 2018;36:903-14; DOI:10.1002/stem.2795.

17. Sugimoto N, Eto K. Platelet production from induced pluripotent stem cells. J Thromb Haemost. 2017;15:1717-27; DOI:10.1111/jth.13736.

18. Filgueiras-Rama D, Vasilijevic J, Jalife J, Noujaim SF, Alfonso JM, Nicolas-Avila JA, Gutierrez C, Zamarreño N, Hidalgo A, Bernabé A, Cop CP, Ponce-Balbuena D, Guerrero-Serna G, Calle D, Desco M, Ruiz-Cabello J, Nieto A, Falcon A. Human influenza A virus causes myocardial and cardiac-specific conduction system infections associated with early inflammation and premature death. Cardiovasc Res. 2020; DOI:10.1093/ cvr/cvaa117.

19. Wang Y, Liang G, Liang S, Mund R, Shi Y, Wei H. Dantrolene ameliorates impaired neurogenesis and synaptogenesis in induced pluripotent stem cell lines derived from patients with alzheimer's disease. Anesthesiology. 2020;132:1062-79; DOI:10.1097/ALN.0000000000003224.

20. Murphy S V., Atala A. 3D bioprinting of tissues and organs. Nat Biotechnol. 2014;32:773-85; DOI:10.1038/nbt.2958.
21. Kačarević ŽP, Rider PM, Alkildani S, Retnasingh S, Smeets R, Jung O, Ivanišević Z, Barbeck M. An introduction to 3D bioprinting: Possibilities, challenges and future aspects. Materials (Basel). 2018;11; DOI:10.3390/ma11112199.

22. Mehrban N, Teoh GZ, Birchall MA. 3D bioprinting for tissue engineering: Stem cells in hydrogels. Int J Bioprinting. 2016;2:6-19; DOI:10.18063/ IJB.2016.01.006.

23. Ashammakhi N, Ahadian S, Xu C, Montazerian H, Ko H, Nasiri R, Barros $\mathrm{N}$, Khademhosseini A. Bioinks and bioprinting technologies to make heterogeneous and biomimetic tissue constructs. Mater Today Bio. 2019;1; DOI:10.1016/j.mtbio.2019.100008.

24. Sorkio A, Koch L, Koivusalo L, Deiwick A, Miettinen S, Chichkov B, Skottman H. Human stem cell based corneal tissue mimicking structures using laser-assisted 3D bioprinting and functional bioinks. Biomaterials. 2018;171:57-71; DOI:10.1016/j.biomaterials.2018.04.034.

25. Malda J, Visser J, Melchels FP, Jüngst T, Hennink WE, Dhert WJA Groll J, Hutmacher DW. 25th anniversary article: Engineering hydrogels for biofabrication. Adv Mater. 2013;25:5011-28; DOI:10.1002/ adma.201302042.

26. Sakai S, Ohi H, Taya M. Gelatin/hyaluronic acid content in hydrogels obtained through blue light-induced gelation affects hydrogel properties and adipose stem cell behaviors. Biomolecules. 2019;9; DOI:10.3390/ biom 9080342 .

27. Lavrentieva A, Kirsch M, Birnstein L, Pepelanova I, Handke W, Rach J Seltsam A, Scheper T. Gelatin-methacryloyl (GelMA) formulated with human platelet lysate supports mesenchymal stem cell proliferation and differentiation and enhances the hydrogel's mechanical properties. Bioengineering. 2019;6; DOI:10.3390/bioengineering6030076.

28. Benning L, Gutzweiler L, Tröndle K, Riba J, Zengerle R, Koltay P, Zimmermann S, Stark GB, Finkenzeller G. Cytocompatibility testing of hydrogels toward bioprinting of mesenchymal stem cells. J Biomed Mater Res - Part A. 2017;105:3231-41; DOI:10.1002/jbm.a.36179.

29. Flanagan LA, Lu J, Wang L, Marchenko SA, Jeon NL, Lee AP, Monuki ES. Unique dielectric properties distinguish stem cells and their differentiated progeny. Stem Cells. 2008;26:656-65; DOI:10.1634/ stemcells.2007-0810.

30. Xavier M, Oreffo ROC, Morgan H. Skeletal stem cell isolation: A review on the state-of-the-art microfluidic label-free sorting techniques. Biotechnol Adv. 2016;34:908-23; DOI:10.1016/j.biotechadv.2016.05.008.

31. Luo J, Nelson EL, Li GP, Bachman M. Microfluidic dielectrophoretic sorter using gel vertical electrodes. Biomicrofluidics. 2014;8; DOI:10.1063/1.4880244.

32. Chan JY, Ahmad Kayani A Bin, Md Ali MA, Kok CK, Yeop Majlis B, Hoe SLL, Marzuki M, Khoo ASB, Ostrikov K, Ataur Rahman M, Sriram S. Dielectrophoresis-based microfluidic platforms for cancer diagnostics. Biomicrofluidics. 2018;12; DOI:10.1063/1.5010158.

33. Yoshioka J, Ohsugi Y, Yoshitomi T, Yasukawa T, Sasaki N, Yoshimoto K. Label-free rapid separation and enrichment of bone marrow-derived mesenchymal stem cells from a heterogeneous cell mixture using a dielectrophoresis device. Sensors (Switzerland). 2018;18; DOI:10.3390/ s18093007.

34. Sawicki W, Malejczyk J, Wróblewska Martyna. Ujarzmienie starzenia: odmładzanie komórek, dedyferencjacja i transdyferencjacja. Gerontol Pol. 2015.

35. Lis R, Karrasch CC, Poulos MG, Kunar B, Redmond D, Duran JGB, Badwe CR, Schachterle W, Ginsberg M, Xiang J, Tabrizi AR, Shido K, Rosenwaks Z, Elemento O, Speck NA, Butler JM, Scandura JM, Rafii S. Conversion of adult endothelium to immunocompetent haematopoietic stem cells. Nature. 2017;545:439-45; DOI:10.1038/nature22326.

36. Dai T-Q, Zhang L-L, An Y, Xu F-F, An R, Xu H-Y, Liu Y-P, Liu B. In vitro transdifferentiation of adipose tissue-derived stem cells into salivary gland acinar-like cells. Am J Transl Res. 2019;11:2908-24.

37. Shivakumar SB, Lee HJ, Son YB, Bharti D, Ock SA, Lee SL, Kang YH, Park $\mathrm{BW}$, Rho GJ. In vitro differentiation of single donor derived human dental mesenchymal stem cells into pancreatic $\beta$ cell-like cells. Biosci Rep. 2019;39; DOI:10.1042/BSR20182051.

38. Grässer U, Bubel M, Sossong D, Oberringer M, Pohlemann T, Metzger W. Dissociation of mono- and co-culture spheroids into single cells for subsequent flow cytometric analysis. Ann Anat. 2018;216:1-8; DOI:10.1016/j.aanat.2017.10.002.

39. Cho CF, Wolfe JM, Fadzen CM, Calligaris D, Hornburg K, Chiocca EA, Agar NYR, Pentelute BL, Lawler SE. Blood-brain-barrier spheroids as an in vitro screening platform for brain-penetrating agents. Nat Commun. 2017;8; DOI:10.1038/ncomms15623.

40. Vorrink SU, Zhou Y, Ingelman-Sundberg M, Lauschke VM. Prediction of drug-induced hepatotoxicity using long-term stable primary hepatic 3D spheroid cultures in chemically defined conditions. Toxicol Sci. 2018;163:655-65; DOI:10.1093/toxsci/kfy058. 
41. Lazzari G, Nicolas V, Matsusaki M, Akashi M, Couvreur P, Mura S. Multicellular spheroid based on a triple co-culture: A novel 3D model to mimic pancreatic tumor complexity. Acta Biomater. 2018;78:296-307; DOI:10.1016/j.actbio.2018.08.008.

42. Quadrato G, Nguyen T, Macosko EZ, Sherwood JL, Yang SM, Berger DR, Maria N, Scholvin J, Goldman M, Kinney JP, Boyden ES, Lichtman JW, Williams ZM, McCarroll SA, Arlotta P. Cell diversity and network dynamics in photosensitive human brain organoids. Nature. 2017;545:4853; DOI:10.1038/nature22047.

43. Pham MT, Pollock KM, Rose MD, Cary WA, Stewart HR, Zhou P, Nolta JA, Waldau B. Generation of human vascularized brain organoids. Neuroreport. 2018;29:588-93; DOI:10.1097/WNR.0000000000001014.

44. Lee SH, Hu W, Matulay JT, Silva M V., Owczarek TB, Kim K, Chua CW, Barlow LMJ, Kandoth C, Williams AB, Bergren SK, Pietzak EJ, Anderson CB, Benson MC, Coleman JA, Taylor BS, Abate-Shen C, McKiernan JM, Al-Ahmadie H, Solit DB, Shen MM. Tumor evolution and drug response in patient-derived organoid models of bladder cancer. Cell. 2018;173:515 528.e17; DOI:10.1016/j.cell.2018.03.017.

45. Sachs N, de Ligt J, Kopper O, Gogola E, Bounova G, Weeber F, Balgobind AV, Wind K, Gracanin A, Begthel H, Korving J, van Boxtel R, Duarte AA Lelieveld D, van Hoeck A, Ernst RF, Blokzijl F, Nijman IJ, Hoogstraat M, van de Ven M, Egan DA, Zinzalla V, Moll J, Boj SF, Voest EE, Wessels L, van Diest PJ, Rottenberg S, Vries RGJ, Cuppen E, Clevers H. A living biobank of breast cancer organoids captures disease heterogeneity. Cell. 2018;172:373-386.e10; DOI:10.1016/j.cell.2017.11.010.

46. Hu H, Gehart H, Artegiani B, LÖpez-Iglesias C, Dekkers F, Basak O, van Es I, Chuva de Sousa Lopes SM, Begthel H, Korving J, van den Born M, Zou C, Quirk C, Chiriboga L, Rice CM, Ma S, Rios A, Peters PJ, de Jong YP, Clevers H. Long-term expansion of functional mouse and human hepatocytes as 3d organoids. Cell. 2018;175:1591-1606.e19; DOI:10.1016/j.cell.2018.11.013.

47. Martin-Piedra MA, Alfonso-Rodriguez CA, Zapater A, Durand-Herrera D, Chato-Astrain J, Campos F, Sanchez-Quevedo MC, Alaminos M, Garzon I. Effective use of mesenchymal stem cells in human skin substitutes generated by tissue engineering. Eur Cell Mater. 2019;37:233-49; DOI:10.22203/eCM.v037a14.

48. Kim BS, Kwon YW, Kong JS, Park GT, Gao G, Han W, Kim MB, Lee H, Kim $\mathrm{JH}$, Cho DW. 3D cell printing of in vitro stabilized skin model and in vivo pre-vascularized skin patch using tissue-specific extracellular matrix bioink: A step towards advanced skin tissue engineering. Biomaterials. 2018;168:38-53; DOI:10.1016/j.biomaterials.2018.03.040.

49. Hirsch T, Rothoeft T, Teig N, Bauer JW, Pellegrini G, De Rosa L, Scaglione D, Reichelt J, Klausegger A, Kneisz D, Romano O, Seconetti AS, Contin R, Enzo E, Jurman I, Carulli S, Jacobsen F, Luecke T, Lehnhardt M, Fischer M, Kueckelhaus M, Quaglino D, Morgante M, Bicciato S, Bondanza S, De Luca M. Regeneration of the entire human epidermis using transgenic stem cells. Nature. 2017;551:327-32; DOI:10.1038/nature24487.

50. Levato R, Webb WR, Otto IA, Mensinga A, Zhang Y, van Rijen M, van Weeren R, Khan IM, Malda J. The bio in the ink: cartilage regeneration with bioprintable hydrogels and articular cartilage-derived progenitor cells. Acta Biomater. 2017;61:41-53; DOI:10.1016/j.actbio.2017.08.005.

51. Lu J, Shen X, Sun X, Yin H, Yang S, Lu C, Wang Y, Liu Y, Huang Y, Yang Z, Dong X, Wang C, Guo Q, Zhao L, Sun X, Lu S, Mikos AG, Peng J, Wang X. Increased recruitment of endogenous stem cells and chondrogenic differentiation by a composite scaffold containing bone marrow homing peptide for cartilage regeneration. Theranostics. 2018;8:5039-58; DOI:10.7150/thno.26981.

52. Neybecker P, Henrionnet C, Pape E, Mainard D, Galois L, Loeuille D, Gillet $\mathrm{P}$, Pinzano A. In vitro and in vivo potentialities for cartilage repair from human advanced knee osteoarthritis synovial fluid-derived mesenchymal stem cells. Stem Cell Res Ther. 2018;9; DOI:10.1186/ s13287-018-1071-2.

53. Jia J, Bai F, Jin Y, Santostefano KE, Ha U-H, Wu D, Wu W, Terada N, Jin S. Efficient gene editing in pluripotent stem cells by bacterial injection of transcription activator-like effector nuclease proteins. Stem Cells Transl Med. 2015;4:913-26; DOI:10.5966/sctm.2015-0030.

54. Lux CT, Pattabhi S, Berger M, Nourigat C, Flowers DA, Negre O, Humbert O, Yang JG, Lee C, Jacoby K, Bernstein I, Kiem HP, Scharenberg A, Rawlings DJ. TALEN-mediated gene editing of hbg in human hematopoietic stem cells leads to therapeutic fetal hemoglobin induction. Mol Ther Methods Clin Dev. 2019;12:175-83; DOI:10.1016/j.omtm.2018.12.008.

55. Gaj T, Gersbach CA, Barbas CF. ZFN, TALEN, and CRISPR/Cas-based methods for genome engineering. Trends Biotechnol. 2013;31:397-405; DOI:10.1016/j.tibtech.2013.04.004.

56. Zhang F, Cong L, Lodato S, Kosuri S, Church GM, Arlotta P. Efficient construction of sequence-specific TAL effectors for modulating mammalian transcription. Nat Biotechnol. 2011;29:149-54; DOI:10.1038/ nbt.1775.
57. Carroll D. Genome engineering with zinc-finger nucleases. Genetics. 2011;188:773-82; DOI:10.1534/genetics.111.131433.

58. Kim YG, Cha J, Chandrasegaran S. Hybrid restriction enzymes: Zinc finger fusions to Fok I cleavage domain. Proc Natl Acad Sci U S A. 1996;93:1156-60; DOI:10.1073/pnas.93.3.1156.

59. Hockemeyer D, Soldner F, Beard C, Gao Q, Mitalipova M, Dekelver RC, Katibah GE, Amora R, Boydston EA, Zeitler B, Meng X, Miller JC, Zhang L, Rebar EJ, Gregory PD, Urnov FD, Jaenisch R. Efficient targeting of expressed and silent genes in human ESCs and iPSCs using zinc-finger nucleases. Nat Biotechnol. 2009;27:851-7; DOI:10.1038/nbt.1562.

60. Gasiunas G, Barrangou R, Horvath P, Siksnys V. Cas9-crRNA ribonucleoprotein complex mediates specific DNA cleavage for adaptive immunity in bacteria. Proc Natl Acad Sci U S A. 2012;109; DOI:10.1073/ pnas.1208507109.

61. Kim HS, Bernitz JM, Lee DF, Lemischka IR. Genomic editing tools to model human diseases with isogenic pluripotent stem cells. Stem Cells Dev. 2014;23:2673-86; DOI:10.1089/scd.2014.0167.

62. Ran FA, Hsu PD, Wright J, Agarwala V, Scott DA, Zhang F. Genome engineering using the CRISPR-Cas9 system. Nat Protoc. 2013;8:2281-308; DOI:10.1038/nprot.2013.143.

63. Jinek M, Chylinski K, Fonfara I, Hauer M, Doudna JA, Charpentier E. A programmable dual-RNA-guided DNA endonuclease in adaptive bacterial immunity. Science. 2012;337:816-21; DOI:10.1126/ science.1225829.

64. Koziński K, Dobrzyń A. Szlak sygnałowy Wnt i jego rola w regulacji metabolizmu komórki. Postepy Hig Med Dosw. 2013;67:1098-108; DOI:10.5604/17322693.1077719.

65. Abdelwahab EMM, Rapp J, Feller D, Csongei V, Pal S, Bartis D, Thickett DR, Pongracz JE. Wnt signaling regulates trans-differentiation of stem cell like type 2 alveolar epithelial cells to type 1 epithelial cells. Respir Res. 2019;20; DOI:10.1186/s12931-019-1176-x.

66. Cai T, Sun D, Duan Y, Wen P, Dai C, Yang J, He W. WNT/ $\beta$-catenin signaling promotes VSMCs to osteogenic transdifferentiation and calcification through directly modulating Runx2 gene expression. Exp Cell Res. 2016;345:206-17; DOI:10.1016/j.yexcr.2016.06.007.

67. Eswari S, Monisha M, Vijayarani K, Kumanan K, TANUVAS. Expression of early transcription factors by mesenchymal stem cells derived from ovine umbilical cord Wharton's Jelly 2016.

68. Satheesan L, Soundian E, Kumanan V, Kathaperumal K. Potential of ovine Wharton jelly derived mesenchymal stem cells to transdifferentiate into neuronal phenotype for application in neuroregenerative therapy. Int ] Neurosci. 2020;130:1101-8; DOI:10.1080/00207454.2020.1725510.

69. Bhuvanalakshmi G, Arfuso F, Kumar AP, Dharmarajan A, Warrier S. Epigenetic reprogramming converts human Wharton's jelly mesenchymal stem cells into functional cardiomyocytes by differential regulation of Wnt mediators. Stem Cell Res Ther. 2017;8:185; DOI:10.1186/ s13287-017-0638-7.

70. Simão VA, Evangelista-Ribeiro CP, Brand H, Lagass-Pereira L, Marques LF, Benites-Aoki PH, Nunes da Silveira-Antunes R, Tonso A, Ribeiro-Paes JT. Metabolic and proliferation evaluation of human adipose-derived mesenchymal stromal cells (ASC) in different culture medium volumes: standardization of static culture. Biologicals. 2019;62:93-101 DOI:10.1016/j.biologicals.2019.08.006.

71. Pereira S, Pinto E, Ribeiro PA, Sério S. Study of a cold atmospheric pressure plasma jet device for indirect treatment of squamous cell carcinoma. Clin Plasma Med. 2019;13:9-14; DOI:10.1016/j. cpme.2018.09.001.

72. Busco G, Omran AV, Ridou L, Pouvesle JM, Robert E, Grillon C. Cold atmospheric plasma-induced acidification of tissue surface: Visualization and quantification using agarose gel models. J Phys D Appl Phys. 2019;52:24LT01; DOI:10.1088/1361-6463/ab1119.

73. Park J, Lee H, Lee HJ, Kim GC, Kim SS, Han S, Song K. Non-thermal atmospheric pressure plasma is an excellent tool to activate proliferation in various mesoderm-derived human adult stem cells. Free Radic Biol Med. 2019;134:374-84; DOI:10.1016/j.freeradbiomed.2019.01.032.

74. Park J, Suh D, Tang T, Lee HJ, Roe JS, Kim GC, Han S, Song K. Non-thermal atmospheric pressure plasma induces epigenetic modifications that activate the expression of various cytokines and growth factors in human mesoderm-derived stem cells. Free Radic Biol Med. 2020;148:108-22; DOI:10.1016/j.freeradbiomed.2019.12.035.

75. Musunuru K. The hope and hype of CRISPR-Cas9 genome editing: A review. JAMA Cardiol. 2017;2:914-9; DOI:10.1001/ jamacardio.2017.1713.

76. Hu X, Li L, Yu X, Zhang R, Yan S, Zeng Z, Shu Y, Zhao C, Wu X, Lei J, Li Y, Zhang W, Yang C, Wu K, Wu Y, An L, Huang S, Ji X, Gong C, Yuan C, Zhang L, Liu W, Huang B, Feng Y, Zhang B, Haydon RC, Luu HH, Reid RR, Lee MJ, Wolf JM, Yu Z, He TC. CRISPR/Cas9-mediated reversibly immortalized mouse bone marrow stromal stem cells (BMSCs) retain 
multipotent features of mesenchymal stem cells (MSCs). Oncotarget. 2017;8:111847-65; DOI:10.18632/oncotarget.22915.

77. Kang JG, Park JS, Ko JH, Kim YS. Regulation of gene expression by altered promoter methylation using a CRISPR/Cas9-mediated epigenetic editing system. Sci Rep. 2019;9; DOI:10.1038/s41598-019-48130-3.

78. Guo X, Tang Y, Zhang P, Li S, Chen Y, Qian B, Shen H, Zhao N. Effect of ectopic high expression of transcription factor OCT4 on the "stemness" characteristics of human bone marrow-derived mesenchymal stromal cells. Stem Cell Res Ther. 2019;10; DOI:10.1186/s13287-019-1263-4.

79. Lavasani M, Thompson SD, Pollett JB, Usas A, Lu A, Stolz DB, Clark KA, Sun B, Péault B, Huard J. Human muscle-derived stem/progenitor cells promote functional murine peripheral nerve regeneration. J Clin Invest. 2014;124:1745-56; DOI:10.1172/JCI44071.

80. Ishida O, Hagino I, Nagaya N, Shimizu T, Okano T, Sawa Y, Mori H, Yagihara T. Adipose-derived stem cell sheet transplantation therapy in a porcine model of chronic heart failure. Transl Res. 2015;165:631-9; DOI:10.1016/j.trsl.2014.12.005.

81. Kim MC, Kim YS, Kang WS, Lee KH, Cho M, Hong MH, Lim KS, Jeong MH, Ahn Y. Intramyocardial injection of stem cells in pig myocardial infarction model: The first trial in Korea. J Korean Med Sci. 2017;32:1708-12; DOI:10.3346/jkms.2017.32.10.1708.

82. Haenel A, Ghosn M, Karimi T, Vykoukal J, Shah D, Valderrabano M Schulz DG, Raizner A, Schmitz C, Alt EU. Unmodified autologous stem cells at point of care for chronic myocardial infarction. World J Stem Cells. 2019;11:831-58; DOI:10.4252/wjsc.v11.i10.831.

83. Chang HK, Kim PH, Kim DW, Cho HM, Jeong MJ, Kim DH, Joung YK, Lim KS, Kim HB, Lim HC, Han DK, Hong YJ, Cho JY. Coronary stents with inducible VEGF/HGF-secreting UCB-MSCs reduced restenosis and increased re-endothelialization in a swine model. Exp Mol Med. 2018;50; DOI:10.1038/s12276-018-0143-9.

84. Tao H, Chen X, Cao H, Zheng L, Li Q, Zhang K, Han Z, Han ZC, Guo Z, Li Z, Wang L. Mesenchymal stem cell-derived extracellular vesicles for corneal wound repair. Stem Cells Int. 2019;2019; DOI:10.1155/2019/5738510.

85. Zhou Y, Chen Y, Wang S, Qin F, Wang L. MSCs helped reduce scarring in the cornea after fungal infection when combined with anti-fungal treatment. BMC Ophthalmol. 2019;19; DOI:10.1186/s12886-019-1235-6.

86. Amini-Nik S, Dolp R, Eylert G, Datu AK, Parousis A, Blakeley C, Jeschke MG. Stem cells derived from burned skin - The future of burn care EBioMedicine. 2018;37:509-20; DOI:10.1016/j.ebiom.2018.10.014.

87. Boltze J, Abe K, Clarkson AN, Detante O, Pimentel-Coelho PM, Rosado-de-Castro PH, Janowski M. Editorial: Cell-based therapies for stroke: promising solution or dead end? Front Neurol. 2020;11; DOI:10.3389/ fneur.2020.00171.

88. Levy ML, Crawford JR, Dib N, Verkh L, Tankovich N, Cramer SC. Phase I/II study of safety and preliminary efficacy of intravenous allogeneic mesenchymal stem cells in chronic stroke. Stroke. 2019;50:2835-41; DOI:10.1161/STROKEAHA.119.026318.

89. Kalladka D, Sinden J, Pollock K, Haig C, McLean J, Smith W, McConnachie A, Santosh C, Bath PM, Dunn L, Muir KW. Human neural stem cells in patients with chronic ischaemic stroke (PISCES): a phase 1, first-in-man study. Lancet. 2016;388:787-96; DOI:10.1016/ S0140-6736(16)30513-X.

90. Muir KW, Bulters D, Willmot M, Sprigg N, Dixit A, Ward N, Tyrrell P, Majid A, Dunn L, Bath P, Howell J, Stroemer P, Pollock K, Sinden J. Intracerebral implantation of human neural stem cells and motor recovery after stroke: Multicentre prospective single-arm study (PISCES-2). J Neurol Neurosurg Psychiatry. 2020;91; DOI:10.1136/jnnp-2019-322515.

91. Duma C, Kopyov O, Kopyov A, Berman M, Lander E, Elam M, Arata M, Weiland D, Cannell R, Caraway C, Berman S, Scord K, Stemler L, Chung K, Khoudari S, McRory R, Duma C, Farmer S, Bravo A, Yassa C, Sanathara A, Singh E, Rapaport B. Human intracerebroventricular (ICV) injection of autologous, non-engineered, adipose-derived stromal vascular fraction (ADSVF) for neurodegenerative disorders: results of a 3-year phase 1 study of 113 injections in 31 patients. Mol Biol Rep. 2019;46:5257-72; DOI:10.1007/s11033-019-04983-5.

92. Berry JD, Cudkowicz ME, Windebank AJ, Staff NP, Owegi M, Nicholson K, McKenna-Yasek D, Levy YS, Abramov N, Kaspi H, Mehra M, Aricha $\mathrm{R}$, Gothelf Y, Brown RH. NurOwn, phase 2, randomized, clinical trial in patients with ALS: Safety, clinical, and biomarker results. Neurology. 2019;93:E2294-305; DOI:10.1212/WNL.0000000000008620.

93. Singer W, Dietz AB, Zeller AD, Gehrking TL, Schmelzer JD, Schmeichel AM, Gehrking JA, Suarez MD, Sletten DM, Minota Pacheco K V., Coon EA, Sandroni P, Benarroch EE, Fealey RD, Matsumoto JY, Bower JH, Hassan A, Mckeon A, Windebank AJ, Mandrekar JN, Low PA. Intrathecal administration of autologous mesenchymal stem cells in multiple system atrophy. Neurology. 2019;93:E77-87; DOI:10.1212/ WNL.0000000000007720.
94. Levi AD, Okonkwo DO, Park P, Jenkins AL, Kurpad SN, Parr AM, Ganju A, Aarabi B, Kim D, Casha S, Fehlings MG, Harrop JS, Anderson KD, Gage A, Hsieh J, Huhn S, Curt A, Guzman R. Emerging safety of intramedullary transplantation of human neural stem cells in chronic cervical and thoracic spinal cord injury. Clin Neurosurg. 2018;82:562-75; DOI:10.1093/neuros/nyx250.

95. Curtis E, Martin JR, Gabel B, Sidhu N, Rzesiewicz TK, Mandeville R, Van Gorp S, Leerink M, Tadokoro T, Marsala S, Jamieson C, Marsala M, Ciacci JD. A First-in-Human, Phase I Study of Neural Stem Cell Transplantation for Chronic Spinal Cord Injury. Cell Stem Cell. 2018;22:941-950.e6; DOI:10.1016/j.stem.2018.05.014.

96. Xiao Z, Tang F, Zhao Y, Han G, Yin N, Li X, Chen B, Han S, Jiang X, Yun C, Zhao C, Cheng S, Zhang S, Dai J. Significant improvement of acute complete spinal cord injury patients diagnosed by a combined criteria implanted with neuroregen scaffolds and mesenchymal stem cells. Cell Transplant. 2018;27:907-15; DOI:10.1177/0963689718766279.

97. Lopez AD, Mathers CD, Ezzati M, Jamison DT, Murray CJ. Global and regional burden of disease and risk factors, 2001: systematic analysis of population health data. Lancet. 2006;367:1747-57; DOI:10.1016/ S0140-6736(06)68770-9.

98. Qi Z, Liu S, Duan F. Effects of bone marrow mononuclear cells delivered through a graft vessel in patients with previous myocardial infarction and chronic heart failure: An echocardiographic study of left ventricular dyssynchrony. J Clin Ultrasound. 2018;46:512-8; DOI:10.1002/ jcu.22609.

99. Kim SH, Cho JH, Lee YH, Lee JH, Kim SS, Kim MY, Lee MG, Kang WY, Lee $\mathrm{KS}$, Ahn YK, Jeong MH, Kim HS. Improvement in left ventricular function with intracoronary mesenchymal stem cell therapy in a patient with anterior wall st-segment elevation myocardial infarction. Cardiovasc Drugs Ther. 2018;32:329-38; DOI:10.1007/s10557-018-6804-z.

100. Fernández-Avilés F, Sanz-Ruiz R, Bogaert J, Plasencia AC, Gilaberte I, Belmans A, Fernández-Santos ME, Charron D, Mulet M, Yotti R, Palacios I, Luque M, Sádaba R, Román JAS, Larman M, Sánchez PL, Sanchís J, Jiménez MF, Claus P, Al-Daccak R, Lombardo E, Abad JL, Delarosa O, Corcóstegui L, Bermejo J, Janssens S. Safety and efficacy of intracoronary infusion of allogeneic human cardiac stem cells in patients with st-segment elevation myocardial infarction and left ventricular dysfunction a multicenter randomized, double-blind, and placebo-controlled clinical trial. Circ Res. 2018;123:579-89; DOI:10.1161/ CIRCRESAHA.118.312823.

101. Bartolucci J, Verdugo FJ, González PL, Larrea RE, Abarzua E, Goset C, Rojo P, Palma I, Lamich R, Pedreros PA, Valdivia G, Lopez VM, Nazzal C, Alcayaga-Miranda F, Cuenca J, Brobeck MJ, Patel AN, Figueroa FE, Khoury M. Safety and efficacy of the intravenous infusion of umbilical cord mesenchymal stem cells in patients with heart failure: A phase $1 / 2$ randomized controlled trial (RIMECARD trial [Randomized clinical trial of intravenous infusion umbilical cord mesenchymal stem cells on cardiopathy]). Circ Res. 2017;121:1192-204; DOI:10.1161/ CIRCRESAHA.117.310712.

102. Bolli R, Hare JM, March KL, Pepine CJ, Willerson JT, Perin EC, Yang PC, Henry TD, Traverse JH, Mitrani RD, Khan A, Hernandez-Schulman I, Taylor DA, DiFede DL, Lima JAC, Chugh A, Loughran J, Vojvodic RW, Sayre SL, Bettencourt J, Cohen M, Moyé L, Ebert RF, Simari RD. Rationale and design of the CONCERT-HF trial (combination of mesenchymal and c-kit + cardiac stem cells as regenerative therapy for heart failure). Circ Res. 2018;122:1703-15; DOI:10.1161/CIRCRESAHA.118.312978.

103. Lee WS, Kim HJ, Kim K Il, Kim GB, Jin W. Intra-articular injection of autologous adipose tissue-derived mesenchymal stem cells for the treatment of knee osteoarthritis: a phase iib, randomized, placebo-controlled clinical trial. Stem Cells Transl Med. 2019;8:504-11; DOI:10.1002/ sctm.18-0122.

104. Song Y, Du H, Dai C, Zhang L, Li S, Hunter DJ, Lu L, Bao C. Human adipose-derived mesenchymal stem cells for osteoarthritis: A pilot study with long-term follow-up and repeated injections. Regen Med. 2018;13:295-307; DOI:10.2217/rme-2017-0152.

105. Lamo-Espinosa JM, Mora G, Blanco JF, Granero-Moltó F, Nuñez-Córdoba JM, Sánchez-Echenique C, Bondía JM, Aquerreta JD, Andreu EJ, Ornilla E, Villarón EM, Valentí-Azcárate A, Sánchez-Guijo F, Cañizo MC, Valentí-Nin JR, Prósper F. Intra-articular injection of two different doses of autologous bone marrow mesenchymal stem cells versus hyaluronic acid in the treatment of knee osteoarthritis: Multicenter randomized controlled clinical trial (phase I/II). J Transl Med. 2016;14; DOI:10.1186/ s12967-016-0998-2.

106. Lamo-Espinosa JM, Mora G, Blanco JF, Granero-Moltó F, Núñez-Córdoba JM, López-Elío S, Andreu E, Sánchez-Guijo F, Aquerreta JD, Bondía JM, Valentí-Azcárate A, Consuelo del Cañizo M, Villarón EM, Valentí-Nin JR, Prósper F. Intra-articular injection of two different doses of autologous bone marrow mesenchymal stem cells versus hyaluronic acid in the 
treatment of knee osteoarthritis: Long-term follow up of a multicenter randomized controlled clinical trial (phase I/II). J Transl Med. 2018;16; DOI:10.1186/s12967-018-1591-7.

107. Park Y-B, Ha C-W, Lee C-H, Yoon YC, Park Y-G. Cartilage regeneration in osteoarthritic patients by a composite of allogeneic umbilical cord blood-derived mesenchymal stem cells and hyaluronate hydrogel: results from a clinical trial for safety and proof-of-concept with 7 years of extended follow-up. Stem Cells Transl Med. 2017;6:613-21; DOI:10.5966/sctm.2016-0157.

108. Garay-Mendoza D, Villarreal-Martínez L, Garza-Bedolla A, Pérez-Garza DM, Acosta-Olivo C, Vilchez-Cavazos F, Diaz-Hutchinson C, Gómez-Almaguer D, Jaime-Pérez JC, Mancías-Guerra C. The effect of intra-articular injection of autologous bone marrow stem cells on pain and knee function in patients with osteoarthritis. Int J Rheum Dis. 2018;21:1407; DOI:10.1111/1756-185X.13139.

109. Carlsson PO, Schwarcz E, Korsgren O, Le Blanc K. Preserved $\beta$-cell function in type 1 diabetes by mesenchymal stromal cells. Diabetes. 2015;64:587-92; DOI:10.2337/db14-0656

110. Bhansali S, Dutta P, Kumar V, Yadav MK, Jain A, Mudaliar S, Bhansali S, Sharma RR, Jha V, Marwaha N, Khandelwal N, Srinivasan A, Sachdeva N, Hawkins M, Bhansali A. Efficacy of autologous bone marrow-derived mesenchymal stem cell and mononuclear cell transplantation in type 2 diabetes mellitus: a randomized, placebo-controlled comparative study. Stem Cells Dev. 2017;26:471-81; DOI:10.1089/scd.2016.0275. 